\section{Quantitative Assessment of Root Canal Roughness with Calcium-Based Hypochlorite Irrigants by 3D CLSM}

Juliana Santos Oliveira, Walter Raucci Neto, Natália Spadine de Faria, Fernanda Silva Fernandes, Carlos Eduardo Saraiva Miranda, Fuad Jacob Abi Rached-Junior
Dental School, University of Ribeirão

Preto, Ribeirão Preto, SP, Brazil

Correspondence: Prof. Dr. Walter Raucci Neto, Rua Alfredo Benzoni, 11, lguatemi, 14091-520 Ribeirão Preto, SP, Brasil. Tel: +55-16-3603-6717. e-mail: rauccineto@yahoo.com.br

\begin{abstract}
Chemical solutions play important roles in endodontic treatment and promote ultrastructural changes in dentin surface. The aim of this study was to quantify root canal roughness at different concentrations of calcium hypochlorite $\left(\mathrm{Ca}(\mathrm{OCI})_{2}\right)$ and sodium hypochlorite $(\mathrm{NaOCl})$ by confocal laser scanning microscopy (CLSM). Fifty-two human mandibular premolars were sectioned and randomly organized into thirteen groups $(n=8)$ : saline (control); $1 \%, 2.5 \%$ and $5 \% \mathrm{NaOCl}_{1} 1 \%, 2.5 \%$ and $5 \% \mathrm{Ca}(\mathrm{OCl})_{2}$; the hypochlorite groups were further divided into with or without EDTA. The chlorine concentrations of the different solutions were measured by iodine titration (\%). The superficial roughness (Sa) was quantified by $\mathrm{CLSM}$. $\mathrm{Ca}(\mathrm{OCl})_{2}$ presented substantial decrease in chlorine concentration that differed from the package indication, but without compromising the dentin ultrastructure changes. There were no significant differences in dentin roughness between $\mathrm{Ca}(\mathrm{OCl})_{2}$ or $\mathrm{NaOCl}$ at all studied concentrations. The combination with EDTA provided similar roughness values among the solutions $(p>0.05)$. The $5 \% \mathrm{Ca}(\mathrm{OCl})_{2}$ and $\mathrm{NaOCl}$ solutions significantly increased dentin roughness and did not differ from the EDTA association $(p>0.05)$. $\mathrm{Ca}(\mathrm{OCl})_{2}$ promoted similar dentin roughness as the $\mathrm{NaOCl}$ at the same concentrations and combined with EDTA. It may be concluded that $\mathrm{Ca}(\mathrm{OCl})_{2}$ modified the root canal dentin roughness similarly to $\mathrm{NaOCl}$, at the same concentrations and EDTA combinations used in this study. $\mathrm{Ca}(\mathrm{OCl})_{2}$ and $\mathrm{NaOCl}$, both at $5 \%$, significantly altered dentin roughness, overcoming EDTA association, thus $\mathrm{Ca}(\mathrm{OCl})_{2}$ concentrations ranging from $1 \%$ to $2.5 \%$ may be suitable solutions for root canal irrigation protocols.
\end{abstract}

Key Words: calcium chlorine, laser scanning confocal microscopy, dentin.

\section{Introduction}

The instrumentation of root canals provides for the effective action of antimicrobial substances. Chemical solutions play important roles in this process lubricating and disinfecting the dentin walls, removal of inorganic material (smear layer) and application of organic tissue solvent (1).

Sodium hypochlorite $(\mathrm{NaOCl})$ has been widely used due to its bactericidal effects (2) and great capacity for organic tissue dissolution (3). However, due to its limited effects on inorganic materials from the smear layer and its cytotoxicity at higher concentrations $(3,4,5)$, alternative solutions have been developed to complement root canal irrigation $(6,7,8)$. Ethylenediamine tetraacetic acid (EDTA) was developed as a predictable means of canal irrigation for smear layer removal and a complement to $\mathrm{NaOCl}$ interaction with root canal systems, without significantly modifying dentin ultrastructure (9).

The influence of chemical solutions on the physicochemical properties of human root canal dentin may also have positive effects on the bond strength of resin-based endodontic sealers $(4,10-12)$. $\mathrm{NaOCl}$ and EDTA increase wettability and surface energy $(13,14)$. However, higher concentrations and longer contact times with $\mathrm{NaOCl}$ may produce irreversible collagen degradation, resulting in negative effects on sealer bond strength due to the shallower penetration into the dentin walls (14), as observed with $5 \% \mathrm{NaOCl}(15)$. Therefore, to avoid dentin erosion, the irrigating solutions should only expose the dentin collagen, interfering minimally with the net structure (16).

The search for new irrigation protocols and chemical solutions had led to experimental studies using calcium hypochlorite $\left(\mathrm{Ca}(\mathrm{OCl})_{2}\right)$, of which bactericidal effects have already been proved $(14,15)$. Additionally, Dutta and Saunders (6) evaluated the organic tissue dissolution and active chlorine release capacity of $\mathrm{Ca}(\mathrm{OCI})_{2}$. These authors verified that a $35-$ min contact with $5 \%$ and $10 \% \mathrm{Ca}(\mathrm{OCI})_{2}$ dissolved organic tissues similarly to $1.36 \%$ and $4.65 \%$ $\mathrm{NaOCl}$. In addition, greater active chlorine reduction by $\mathrm{Ca}(\mathrm{OCl})_{2}$ solutions was observed.

Due to the scarcity of $\mathrm{Ca}(\mathrm{OCI})_{2}$ studies in endodontics, the aim of this study was to evaluate the active chlorine concentrations (iodometric titration) and the effects of different concentrations of $\mathrm{Ca}(\mathrm{OCl})_{2}(1 \%, 2.5 \%$ and $5 \%)$ and $\mathrm{NaOCl}(1 \%, 2.5 \%$ and $5 \%)$, combined or not with 17\% EDTA, on the superficial roughness of lumen radicular dentin (using 3D confocal laser scanning microscopy). 


\section{Material and Methods}

This study was approved by the Research Ethics Committee of the University of Ribeirão Preto (CAAE: 24590813.6.0000.5498).

\section{Sample and Irrigation Solution Preparation}

Fifty-two mandibular premolars, with fully formed roots, single root canals, absence of calcifications, fractures and/or accentuated curvatures, were washed in running water for $24 \mathrm{~h}$ to eliminate the residue of $0.1 \%$ thymol in which they were stored for decontamination. The teeth were transversally sectioned near the cementoenamel junction, with a water-cooled diamond disc (KG Sorensen, Barueri, SP, Brazil) at low speed. Each root was embedded in an acrylic plate and was longitudinally sectioned with a water-cooled diamond disc in a cutting machine (ISOMET 1000; Buehler, Lake Forest, IL, USA), obtaining 104 samples, to allow better visualization of the irrigating solutions' effect on the root canal walls.

The $1 \%, 2.5 \%$ and $5 \% \mathrm{NaOCl}$ solutions were purchased from a local pharmacy business (Farmácia da Terra, Ribeirão Preto, SP, Brazil), which warranted recent $(24 \mathrm{~h})$ bottling process. The 17\% EDTA was obtained at a local dental store $\dot{\Xi}$ (Biodinâmica, Ibiporã, PR, Brazil). The 1\%, 2.5\% and 5\% $\mathrm{Ca}(\mathrm{OCl})_{2}$ solutions were obtained by dissolution of the pure solid chemical component (HTH; Arch Química Brasil Ltda, Igarassu, PE, Brazil) in distilled water (weight/volume) at the Chemistry Laboratory of the University of Ribeirão Preto. The dissolution of the $\mathrm{Ca}(\mathrm{OCl})_{2}$ materials was made upon 10 min of agitation using a magnetic stirrer (Phoenix mod. AP 56 , Araraquara, SP, Brazil). All the chemical solutions were used in the experiments $24 \mathrm{~h}$ after the bottling process. The concentrations of active chlorine in all of the tested solutions were measured by iodometric titration.

\section{Iodometric Titration}

Five study groups containing $\mathrm{NaOCl}$ and $\mathrm{Ca}(\mathrm{OCl})_{2}$ solutions were evaluated for changes in the concentration of active chlorine. Each procedure was repeated three times for each sample (9), and the evaluation groups were as follows: $\mathrm{G} 1-1 \% \mathrm{Ca}(\mathrm{OCI})_{2} ; \mathrm{G} 2-2.5 \% \mathrm{Ca}(\mathrm{OCl})_{2}$; $\mathrm{G} 3-5 \% \mathrm{Ca}(\mathrm{OCl})_{2 ;} \mathrm{G} 4-1 \% \mathrm{NaOCl} ; \mathrm{G} 5-2.5 \% \mathrm{NaOCl}$ and $\mathrm{G} 6-5 \% \mathrm{NaOCl}$.

Five milliliters of a $4 \%$ solution of potassium iodide (KI) was transferred to a $125 \mathrm{~mL}$ Erlenmeyer flask. Then, $1 \mathrm{~mL}$ was added to the sample, followed by $4 \mathrm{~mL}$ of glacial acetic acid $2.5 \mathrm{~mol} / \mathrm{L}$, and the volume completed with water to $50 \mathrm{~mL}$ with a beaker.

The released iodine was titrated with sodium thiosulfate solution $0.1 \mathrm{~mol} / \mathrm{L}$ until the medium became light yellow. Then, the titration was stopped by adding 10 drops of starch solution, after which it resumed until the solution became colorless. The equivalent volume was recorded, and the percentages of active chlorine in the solutions were calculated.

\section{Root Canal Lumen Dentin Irrigation Protocols}

The specimens were fixed with utility wax in acrylic resin stubs and were divided according to the used irrigation solution ( $\mathrm{n}=8)$ : I - saline; II - $1 \% \mathrm{Ca}(\mathrm{OCI})_{2} ; \mathrm{III}-1 \% \mathrm{Ca}(\mathrm{OCI})_{2}$ $+17 \%$ EDTA; IV - 2.5\% Ca(OCI) $)_{2 i} \mathrm{~V}-2.5 \% \mathrm{Ca}(\mathrm{OCl})_{2}+17 \%$ EDTA; VI - 5\% Ca(OCI $)_{2} ; \mathrm{VII}-5 \% \mathrm{Ca}(\mathrm{OCl})_{2}+17 \%$ EDTA; VIII - 1\% NaOCl; IX - 1\% NaOCl + 17\% EDTA; X - 2.5\% $\mathrm{NaOCl} ; \mathrm{XI}-2.5 \% \mathrm{NaOCl}+17 \% \mathrm{EDTA} ; \mathrm{XII}-5 \% \mathrm{NaOCl} ;$ and XIII $-5 \% \mathrm{NaOCI}+17 \%$ EDTA.

In groups I, II, IV, VI, VIII, X and XII, irrigation was performed with $1 \mathrm{~mL}$ of each solution, aspirated and refreshed every $5 \mathrm{~min}$ repeatedly for a total of $35 \mathrm{~min}$ of contact of the solution with the root canal walls. For groups III, V, VII, IV, XI and XIII, irrigation was performed as described for the other groups, followed by irrigation with $1 \mathrm{~mL}$ of $17 \%$ EDTA for $5 \mathrm{~min}$.

At the end of the experiment, all specimens were irrigated with $20 \mathrm{~mL}$ of distilled water and dried with absorbent paper points (Dentsply-Herpo, Petrópolis, RJ, Brazil).

\section{Superficial Roughness Analysis (Sa)}

The specimens were stored in distilled and deionized water at $4{ }^{\circ} \mathrm{C}$ until the analysis of surface roughness, which was performed by an OLS4000 LEXT (Olympus Corporation, Tokyo, Japan) confocal laser scanning microscope (CLSM). The specimens were fixed on glass slides, keeping the surface of the root canal parallel to the slide surface, hence perpendicular to the microscope objective. For this procedure, a parallelometer and an adhesive material (Pritt; Henkel, Mexico, DF, Mexico) were used.

An image was obtained from the center of the root canal with a $20 \times$ objective, which provided final magnification of 200 times the original size of the sample. The microscope had a 405-nm semiconductor laser that allowed for threedimensional reading of the surface roughness $\left(\mu \mathrm{m}^{2}\right)$. For each specimen, a central area of the root middle third was selected and measurement of surface roughness was obtained (Sa - conforms to ISO25178) from a delimited area of $0,04 \mathrm{~mm}^{2}$. Representative images of each group were selected for qualitative topography analysis.

\section{Statistical Analysis}

The roughness data were analyzed by the KruskalWallis $(\alpha=1 \%)$ and Student-Newman-Keuls tests. All of the statistical procedures were performed using SigmaStat software, version 3.5 (Systat Software Inc., USA). A significance level of $5 \%$ was established for all analyses. 


\section{Results}

lodometric titration was used to determine the concentrations of chlorine available in the solutions. The values of the concentrations of active chlorine (mass/ volume - $\mathrm{m} / \mathrm{v}$ ) contained in the evaluated irrigating substances are exhibited in Table 1.

In all $\mathrm{Ca}(\mathrm{OCl})_{2}$ concentrations, the values of active chlorine available were lower than those stated on the commercial packages. The $1 \% \mathrm{NaOCl}$ solution showed a concentration of active chlorine comparable to the one described in the commercial package (0\% loss). A minimal reduction of this value occurred with the $2.5 \%$ concentration (6.4\% loss) and with 5\% concentration (4\% loss).

Roughness values of the root canals with the different irrigation protocols are in Table 2. The group irrigated with saline showed the lowest values of surface roughness, which were significantly different from those in the other groups $(p<0.05)$.

Comparing the different formulations of hypochlorite $\left(\mathrm{Ca}(\mathrm{OCl})_{2}\right.$ and $\left.\mathrm{NaOCl}\right)$, when applied alone, the $1 \%$ and $2.5 \%$ concentrations promoted surface roughness values that were statistically similar to each other ( $p>0.05)$. However, the same concentrations produced greater roughness values when combined with $17 \%$ EDTA $(p<0.05)$. Use of 17\% EDTA with concentrations of $1 \%$ and $2.5 \% \mathrm{Ca}(\mathrm{OCl})_{2}$ and $\mathrm{NaOCl}$ showed similar results ( $p>0.05)$.

The highest roughness values were observed with $5 \%$ $\mathrm{Ca}(\mathrm{OCl})_{2}$ and $5 \% \mathrm{NaOCl}$ with and without $17 \%$ EDTA, which were statistically similar ( $p>0.05$ ).

Figures 1 and 2 show representative CLSM images of the root canal surface topography achieved with each irrigation protocol. The EDTA association, regardless the hypochlorite formulation, produced irregular dentin surface (Fig. 2). However the $1 \%$ and $2.5 \%$ concentrations of $\mathrm{Ca}(\mathrm{OCl})_{2}$ and $\mathrm{NaOCl}$ used alone promoted smoother surfaces, similar to the saline group (Fig. 1). The $5 \% \mathrm{Ca}(\mathrm{OCl})_{2}$ and $\mathrm{NaOCl}$ groups presented irregular dentin surface similar to the EDTA association groups.

\section{Discussion}

Irrigating solutions are used in endodontics to

Table 1. Average concentration of active chlorine of the evaluated substances

\begin{tabular}{lcc}
\hline Irrigation solution & Mean $\left(\mathrm{Cl}_{2}\right)(\%) \mathrm{m} / \mathrm{v}$ & Chlorine loss (\%) \\
\hline $1 \% \mathrm{NaOCl}$ & 1.04 & $0 \%$ \\
$2.5 \% \mathrm{NaOCl}$ & 2.34 & $6.4 \%$ \\
$5 \% \mathrm{NaOCl}$ & 4.80 & $4 \%$ \\
$1 \% \mathrm{Ca}(\mathrm{OCl})_{2}$ & 0.79 & $21 \%$ \\
$2.5 \% \mathrm{Ca}(\mathrm{OCl})_{2}$ & 1.86 & $25.6 \%$ \\
$5 \% \mathrm{Ca}(\mathrm{OCl})_{2}$ & 3.61 & $27.8 \%$
\end{tabular}

complement the mechanical action of endodontic instruments for the cleaning and disinfection of root canals (1). They act by causing physical and chemical changes in the ultrastructure of the root dentin, thus decreasing microhardness and increasing dentin permeability $(4,10-$ 12). Regarding the intensity of the effects of these solutions, there is a direct correlation between the used concentrations of the substances and the alterations in the dentin substrate (17).

In the present study, when $\mathrm{Ca}(\mathrm{OCl})_{2}$ was compared to $\mathrm{NaOCl}$ at the $1 \%$ and $2.5 \%$ concentrations, no statistically significant differences concerning the root surface roughness were observed. Thus, regardless the used type of hypochlorite, the changes in the dentin roughness of root canals with these concentrations, may be equivalent and considered appropriate for the biomechanical preparation of root canals as already described for $1 \%$ and $2.5 \% \mathrm{NaOCl}$ (2). These results corroborate the CLSM images (Figs. 1B-1E) as the $1 \%$ and $2.5 \%$ groups $\left(\mathrm{Ca}(\mathrm{OCl})_{2}\right.$ and $\mathrm{NaOCl}$ used alone) presented flat surfaces, similar to the saline group (Fig. 1A).

For the specimens irrigated with $5 \% \mathrm{Ca}(\mathrm{OCI})_{2}$ and $5 \%$ $\mathrm{NaOCl}$ were observed the highest values of roughness, regardless of the association with 17\% EDTA. This finding could be related to the high concentration of active chlorine available with those solutions $\left(\mathrm{Ca}(\mathrm{OCI})_{2}-3.61 \%\right.$ and $\mathrm{NaOCl}-4.80 \%)$, which most likely led to increased

Table 2. Superficial lumen dentin roughness of the different solutions tested

\begin{tabular}{lc}
\hline Irrigation protocol & Mean $\left(\mu \mathrm{m}^{2}\right) \pm$ S.D. \\
\hline Saline & $0.40 \pm 0.13^{\mathrm{A}}$ \\
$1 \% \mathrm{Ca}(\mathrm{OCl})_{2}$ & $1.73 \pm_{0.80^{\mathrm{C}}}$ \\
$1 \% \mathrm{Ca}(\mathrm{OCl})_{2} 1 \%+17 \%$ EDTA & $0.82 \pm 0.42^{\mathrm{B}}$ \\
$2.5 \% \mathrm{Ca}(\mathrm{OCl})_{2}$ & $1.98 \pm 0.99^{\mathrm{C}}$ \\
$2.5 \% \mathrm{Ca}(\mathrm{OCl})_{2}+17 \%$ EDTA & $2.59 \pm 0.31^{\mathrm{D}}$ \\
$5 \% \mathrm{Ca}(\mathrm{OCl})_{2}$ & $2.58 \pm 1.05^{\mathrm{D}}$ \\
$5 \% \mathrm{Ca}(\mathrm{OCl})_{2}+17 \%$ EDTA & $0.83 \pm 0.48^{\mathrm{B}}$ \\
$1 \% \mathrm{NaOCl}$ & $1.28 \pm 1.02^{\mathrm{C}}$ \\
$1 \% \mathrm{NaOCl}+17 \%$ EDTA & $0.86 \pm 0.46^{\mathrm{B}}$ \\
$2.5 \% \mathrm{NaOCl}$ & $1.41 \pm 0.69^{\mathrm{C}}$ \\
$2.5 \% \mathrm{NaOCl}+17 \%$ EDTA & $2.61 \pm 0.52^{\mathrm{D}}$ \\
$5 \% \mathrm{NaOCl}$ & $3.00 \pm 0.72^{\mathrm{D}}$ \\
$5 \% \mathrm{NaOCl}+17 \%$ EDTA &
\end{tabular}

*Same letters indicate statistical similarity $(\mathrm{p}<0.05)$ 

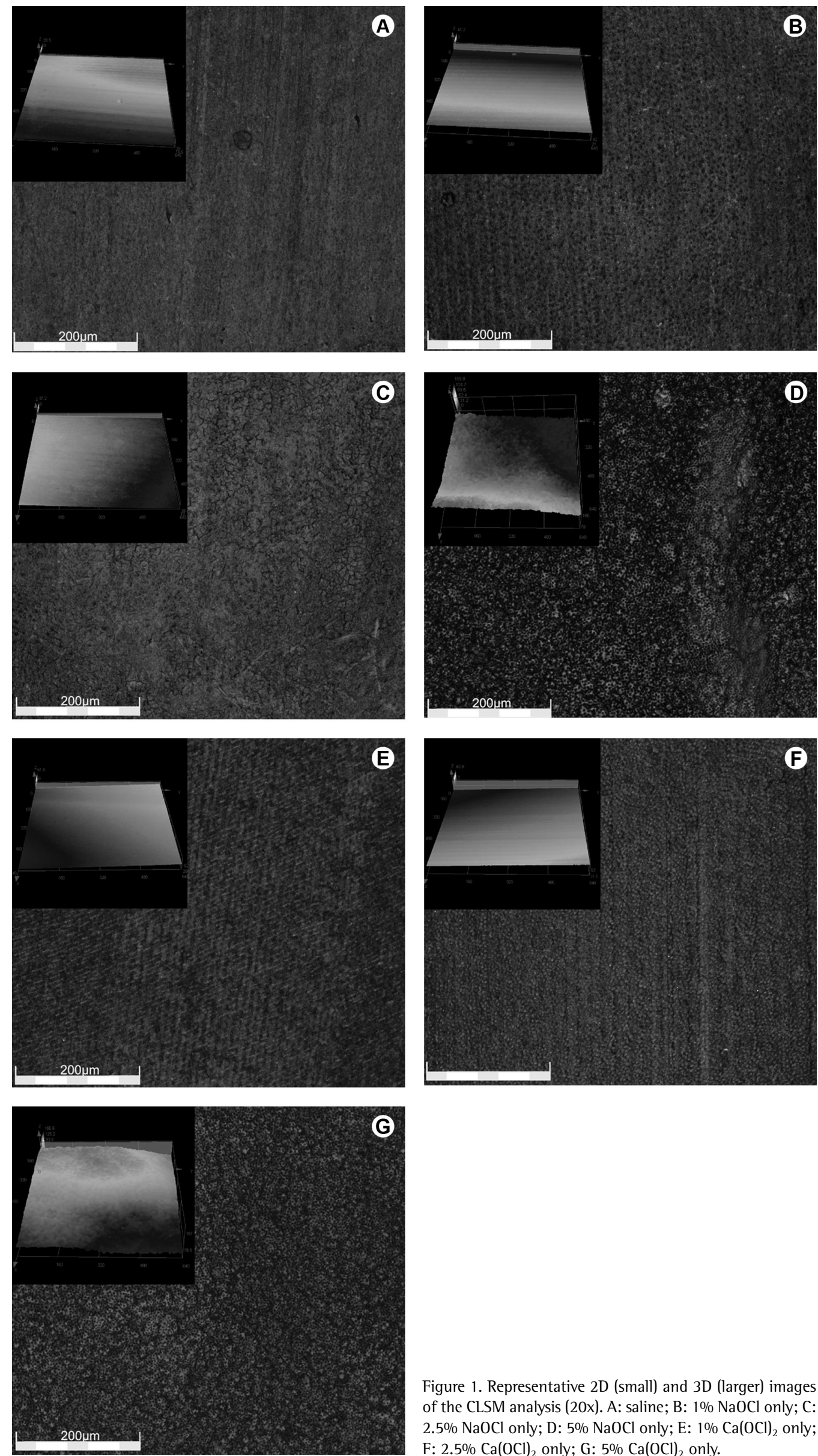

G

Figure 1. Representative 2D (small) and 3D (larger) images of the CLSM analysis (20x). A: saline; $\mathrm{B}: 1 \% \mathrm{NaOCl}$ only; C: $2.5 \% \mathrm{NaOCl}$ only; D: $5 \% \mathrm{NaOCl}$ only; $\mathrm{E}: 1 \% \mathrm{Ca}(\mathrm{OCl})_{2}$ only; F: $2.5 \% \mathrm{Ca}(\mathrm{OCl})_{2}$ only; $\mathrm{G}: 5 \% \mathrm{Ca}(\mathrm{OCl})_{2}$ only. 
degradation of the organic part of the root dentin, resulting in a higher dentin permeability and roughness $(5,18)$. The tested hypothesis is that high concentrations of $\mathrm{Ca}(\mathrm{OCI})_{2}$ and $\mathrm{NaOCl}$ significantly increase dentin permeability and may lead to greater sequestration of calcium ions, increasing therefore the surface demineralization. According to Zhang et al. (18) the superficial destructive effect on mineralized dentin with $5.25 \% \mathrm{NaOCl}$ is irreversible and irrespective of whether EDTA is subsequently employed. These results support the hypothesis that $5 \% \mathrm{Ca}(\mathrm{OCl})_{2}$ could act as a chelating solution causing inadvertent erosion of the canal walls. On that account, the use of $\mathrm{Ca}(\mathrm{OCl})_{2}$ and $\mathrm{NaOCl}$ at concentrations greater than $5 \%$ should be reevaluated as an irrigating solution, because it significantly altered dentin roughness and could hinder the adhesion of endodontic sealers to dentin. As shown in Figures $1 \mathrm{~F}$ and $1 \mathrm{G}$, the
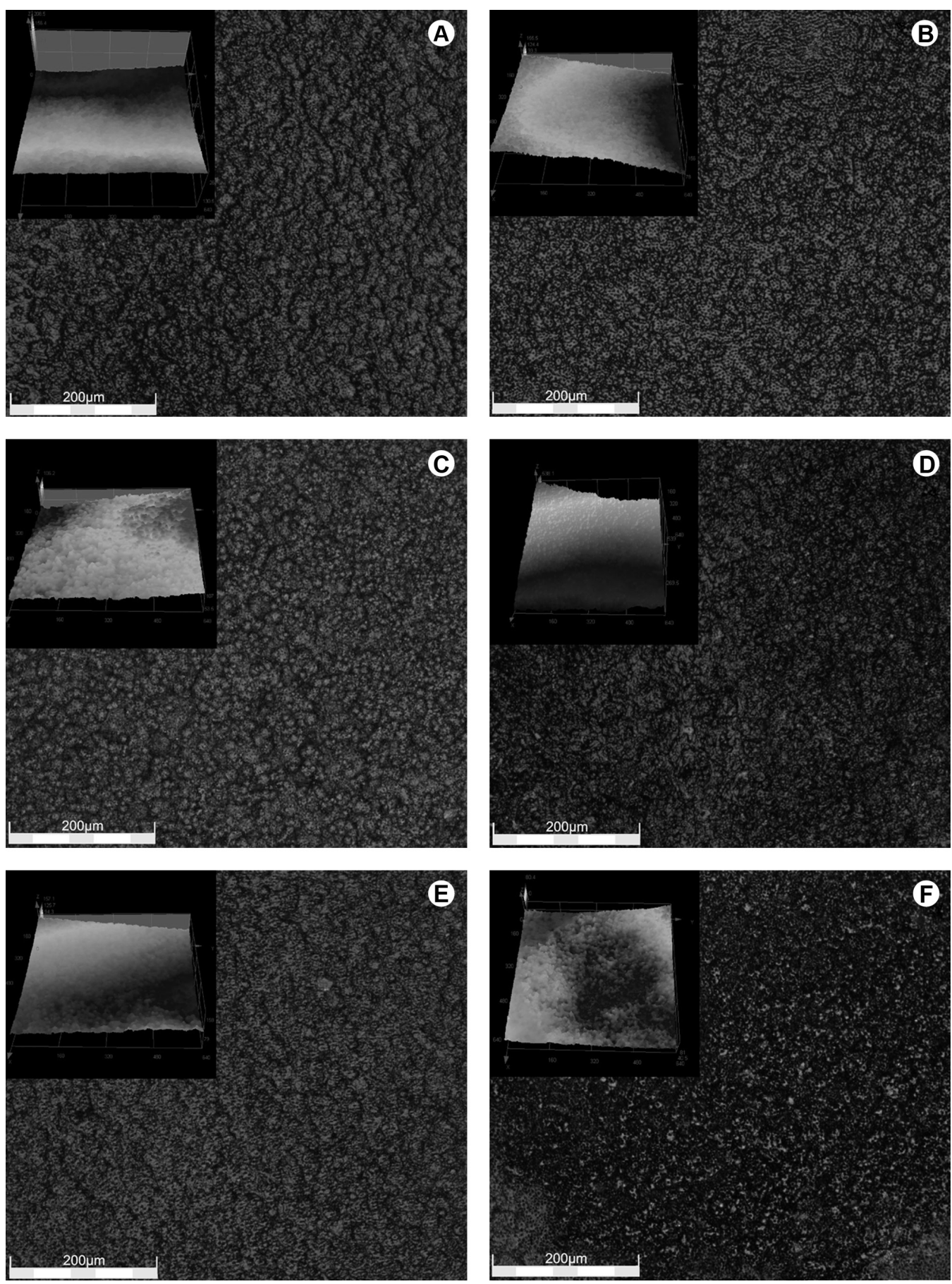

Figure 2. Representative 2D (small) and 3D (larger) images of the CLSM analysis (20x). A: 1\% NaOC+EDTA; B: 2.5\% NaOCl+EDTA; C: 5\% NaOCl+EDTA; D: $1 \% \mathrm{Ca}(\mathrm{OCl})_{2}+$ EDTA; E: $2.5 \% \mathrm{Ca}(\mathrm{OCl})_{2}+$ EDTA; F: 5\% $\mathrm{Ca}(\mathrm{OCl})_{2}+$ EDTA. 
increased dentin roughness with $5 \% \mathrm{NaOCl}$ and $5 \% \mathrm{Ca}(\mathrm{OCl})_{2}$ can be related to the irregular surface topography, similar only to the EDTA association (Fig. 2).

The concentrations of active chlorine available in the studied different solutions were evaluated by iodometric titration. One of the most important effects with regard to the amount of active chlorine in halogen compounds is related to the remaining pulp tissue dissolution capacity (6). The available chlorine in hypochlorite solutions promotes a reaction of chloramines that interfere directly in the bacterial cell metabolism (2). Bacterial oxidation promotes irreversible enzyme inhibition, as well as the replacement of hydrogen by chlorine. This enzyme inactivation can be observed in the reactions of chlorine with amino groups, promoting irreversible oxidation of the sulfhydryl groups of bacterial enzymes. Furthermore, the available chlorine in hypochlorite operates in the saponification reaction when this agent degrades fatty acids and lipids, contributing to the tissue dissolution (19).

In this study it was observed that $1 \%$ and $5 \% \mathrm{NaOCl}$ showed similar concentrations of active chlorine, compared to the value that is stated in the package $(1.04 \%$ and $4.80 \%$ respectively). Minimal changes were observed at $2.5 \% \mathrm{NaOCl}$ concentration, where the available chlorine value decreased to $2.34 \%$, corresponding to a $6.4 \%$ chlorine loss. In contrast, for $\mathrm{Ca}(\mathrm{OCI})_{2}$, the concentrations of active chlorine were significantly lower than those claimed on the commercial packaging. The $1 \% \mathrm{Ca}(\mathrm{OCl})_{2}$ solution had a concentration of active chlorine equal to $0.79 \%$ (21\% loss). At the $2.5 \%$ concentration, this value decreased to $1.86 \%$ (loss of $25.6 \%$ ) and at 5\%, to $3.61 \%$ (loss of $27.8 \%$ ). The present results were slightly different from the findings of Dutta and Saunders (6), who observed 4.15\% active chlorine with $5 \% \mathrm{Ca}(\mathrm{OCI})_{2}$ solutions. However, according to the same authors, there was initially a slow decrease in available chlorine due to its low solubility, and upon dissociation, there was a higher available chlorine content than with the $\mathrm{NaOCl}$ solutions. Although $\mathrm{Ca}(\mathrm{OCl})_{2}$ showed lower concentrations of available chlorine than $\mathrm{NaOCl}$, the surface dentin roughness alterations promoted by both solutions were similar. These results may be explained by the slow chlorine release and final higher chlorine content after 35 min of contact with the tissue (6). Thus, even less than expected, the initial chlorine release of $\mathrm{Ca}(\mathrm{OCI})_{2}$ did not seem to compromise its action on root canals walls.

EDTA enhances the removal of the smear layer in the root canal, thereby increasing the chemical interaction of irrigating solutions with the dentinal walls (14). Sodium hypochlorite reacts mainly with the organic matrix of dentin, increasing its permeability to the chelating agent EDTA, which in turn operates in the inorganic matrix, resulting in increased surface roughness (5). In this study, it was observed that an irrigating solution combined with EDTA could substantially increase roughness, as it occurred with $1 \%$ and $2.5 \%$ concentrations of $\mathrm{Ca}(\mathrm{OCl})_{2}$ and $\mathrm{NaOCl}$. The irrigation protocols without 17\% EDTA presented lower roughness and dentin surface topography similar to saline. However, both solutions at 5\% significantly increased dentin roughness, overcoming the EDTA associations. A positive factor in altering the permeability and roughness of root canal dentin is the extended area of dentin surface available for the adhesion of endodontic sealers $(20,21)$. However, excessive expansion of this area could be followed by the formation of voids, which interfere with the spreading of material on the dentin surface, thus compromising the interface and decreasing adhesion (19). In this sense, under transmission electron microscopy (TEM), Zhang, et al. (18) observed that the subsurface erosion extended 10-15 $\mu \mathrm{m}$ beneath the sealer-bonded dentin surface after using 5.25\% $\mathrm{NaOCl}$ for $20 \mathrm{~min}$.

There has been some concern about the erosive effects of irrigating solutions because the alterations in the dentin surface may affect the interactions with root canal filling materials and decrease the resistance to the penetration of bacteria and apical leakage (22). Therefore, further studies are needed to better assess the relationships between the critical values of roughness and the dentin bond strength of endodontic sealers and fracture resistance of the root canal. Furthermore, due to the slower chlorine release of $\mathrm{Ca}(\mathrm{OCl})_{2}(6)$, it would also be interesting to evaluate the cytotoxicity of its 5\% solution to the periapical tissues, as already described for $5 \% \mathrm{NaOCl}$ (23).

Based on the findings of the present study, it may be concluded that $\mathrm{Ca}(\mathrm{OCI})_{2}$ modified the root canal dentin roughness similarly to $\mathrm{NaOCl}$, at the same concentrations and EDTA combinations used in this study. $\mathrm{Ca}(\mathrm{OCl})_{2}$ and $\mathrm{NaOCl}$, both at $5 \%$, significantly altered dentin roughness, overcoming EDTA association, thus $\mathrm{Ca}(\mathrm{OCI})_{2}$ concentrations ranging from $1 \%$ to $2.5 \%$ could represent suitable solutions for root canal irrigation protocols.

\section{Resumo}

Soluções químicas são fundamentais para o tratamento endodôntico; entretanto, promovem alterações ultraestruturais na superfície dentinária. 0 objetivo deste estudo foi quantificar a rugosidade da dentina radicular com diferentes concentrações de hipoclorito de cálcio $\left(\mathrm{Ca}(\mathrm{OCl})_{2}\right)$ e hipoclorito de sódio $(\mathrm{NaOCl})$ utilizando microscopia confocal à laser (CLSM). Foram utilizados 52 premolares humanos inferiores e aleatoriamente divididos em treze grupos $(n=8)$ : Soro fisiológico (controle); $\mathrm{NaOCl}$ a $1 \%, 2,5 \%$ and $5 \% ; \mathrm{Ca}(\mathrm{OCl})_{2}$ a $1 \%, 2,5 \%$ and $5 \%$; os grupos de hipoclorito foram subdivididos pela associação ou não ao ácido etilenodiaminotetracético (EDTA). A concentração de cloro ativo foi avaliada para diferentes soluções utilizando titulação iodométrica (\%). A rugosidade superficial (Sa) foi quantificada por $\mathrm{CLSM}$. $\mathrm{Ca}(\mathrm{OCI})_{2}$ apresentou perda substancial de cloro ativo e que foi distinta da condição descrita pelo fabricante, sem entretanto comprometer as alterações no substrato dentinário. Não houve diferenças significantes na rugosidade dentinária 
produzida pelos $\mathrm{Ca}(\mathrm{OCl})_{2}$ e $\mathrm{NaOCl}$ em todas as concentrações estudadas e associação com EDTA. A associação ao EDTA produziu rugosidade semelhante entre as soluções $(p>0.05) .0 \mathrm{Ca}(\mathrm{OCl})_{2} \mathrm{e} \mathrm{NaOCI}$ na concentração de $5 \%$ aumentaram significativamente a rugosidade dentinária e não apresentaram diferenças dos valores obtidos com a associação de EDTA $(p>0.05) .0 \mathrm{Ca}(0 \mathrm{Cl})_{2}$ alterou a rugosidade da dentina radicular de forma semelhante ao $\mathrm{NaOCl}$, nas concentrações e associações utilizadas neste estudo. Como a concentração de $5 \%$ de $\mathrm{Ca}(\mathrm{OCl})_{2}$ e $\mathrm{NaOCl}$, apresentou maior rugosidade dentinária, independente da associação ao EDTA, pode-se concluir que $\mathrm{Ca}(\mathrm{OCI})_{2}$ nas concentrações de $1 \%$ e $2,5 \%$ pode ser considerado uma solução adequada para a irrigação de canais radiculares.

\section{Acknowledgements}

The authors would like to thank Dr. Juliana Jendiroba Faraoni Romano for her contributions during the confocal laser scanning microscopy analyses. The authors would like to state that there are no conflicts of interest related to this study.

\section{References}

1. Morgental RD, Singh A, Sappal H, Kopper PM, Vier-Pelisser FV, Peters OA. Dentin inhibits the antibacterial effect of new and conventional endodontic irrigants. J Endod 2013;39:406-410.

2. Bryce G, O'Donnell D, Ready D, Ng YL, Pratten J, Gulabivala K. Contemporary root canal irrigants are able to disrupt and eradicate single and dual-species biofilms J Endod 2009;35:1243-1248.

3. De-Deus G, de Berredo Pinho MA, Reis C, Fidel S, Souza E, Zehnder M. Sodium hypochlorite with reduced surface tension does not improve in situ pulp tissue dissolution. Biofilms. J Endod 2013;39:1039-1043.

4. Dai L, Khechen K, Khan S, Gillen B, Loushine BA, Wimmer CE, et al.. The effect of QMix, an experimental antibacterial root canal irrigant, on removal of canal wall smear layer and debris. J Endod 2011;37:80-84.

5 Ring KC, Murray PE, Namerow KN, Kuttler S, Garcia-Godoy F. The comparison of the effect of endodontic irrigation on cell adherence to root canal dentin. J Endod 2008;34:1474-1479.

6. Dutta A, Saunders WP. Comparative evaluation of calcium hypochlorite on soft tissue dissolution. J Endod 2012;38:1395-1398.

7. Kim HS, Zhu Q, Baek SH, Jung IY, Son WJ, Chang SW, et al.. Chemical interaction of alexidine and sodium hypochlorite. J Endod 2012;38:112-6

8. Prado $M$, Santos Júnior $H M$, Rezende $C M$, Pinto $A C$, Faria $R B$, Simão RA, et al.. Interactions between irrigants commonly used in endodontic practice: a chemical analysis. J Endod. 2013;39:505-10.

9. Ulusoy Öİ, Görgül G. Effects of different irrigation solutions on root dentine microhardness, smear layer removal and erosion. Aust Endod J 2013; 39:66-72.
10. Ari $\mathrm{H}$, Yaşar $\mathrm{E}$, Belli $\mathrm{S}$. Effects of $\mathrm{NaOCl}$ on bond strengths of resin cements to root canal dentin. J Endod 2003;29:248-251.

11. Babb BR, Loushine RJ, Bryan TE, Ames JM, Causey MS, Kim J, et al.. Bonding of self adhesive (self-etching) root canal sealers to radicular dentine. J Endod 2009;35:578-582.

12. Neelakantan P, Subbarao C, Subbarao CV, De-Deus G, Zehnder M. The impact of root dentine conditioning on sealing ability and pushout bond strength of an epoxy resin root canal sealer. Int Endod J 2011;44:491-498.

13. Hu X, Ling J, Gao Y. Effects of irrigation solutions on dentin wettability and roughness. J Endod 2010;36:1064-1067.

14. Yilmaz Z, Basbag B, Buzoglu HD, Gümüsderelioglu M. Effect of low surface tension EDTA solutions on the wettability of root canal dentin. Oral Surg Oral Med Oral Pathol Oral Radiol Endod 2011;111:109-114.

15. Marending M, Luder HU, Brunner TJ, Knecht S, Stark WJ, Zehnder M. Effect of sodium hypochlorite on human root dentine-mechanical, chemical and structural evaluation. Int Endod 2007;40:786-793.

16. Nunes VH, Silva RG, Alfredo $E$, Sousa-Neto MD, Silva-Sousa YT. Adhesion of Epiphany and AH Plus sealers to human root dentine treated with different solutions. Braz Dent J 2008;19:46-50.

17. Slutzky-Goldberg I, Maree M, Liberman R, Heling I. 2004. Effect of sodium hypochlorite on dentin microhardness. J Endod 2004;30:880882.

18. Zhang K, Tay FR, Kim YK, Mitchell JK, Kim JR, Carrilho M, et al.. The effect of initial irrigation with two different sodium hypochlorite concentrations on the erosion of instrumented radicular dentin. Dent Mater 2010;26:514-523.

19. Estrela C, Estrela CR, Barbin EL, Spanó JC, Marchesan MA, Pécora JD. Mechanism of action of sodium hypochlorite. Braz Dent J 2002;13:113117.

20. Kokkas AB, Boutsioukis ACh, Vassiliadis LP, Stavrianos CK. The influence of the smear layer on dentinal tubule penetration depth by three different root canal sealers: an in vitro study. J Endod 2004;30:100-102.

21. Vilanova WV, Carvalho-Junior JR, Alfredo E, Sousa-Neto MD, SilvaSousa YT. Effect of intracanal irrigants on the bond strength of epoxy resin-based and methacrylate resin-based sealers to root canal walls. Int Endod J 2012;45:42-48

22. Aranda-Garcia AJ, Kuga MC, Chavéz-Andrade GM, Kalatzis-Sousa NG, Hungaro Duarte MA, Faria G, et al.. Effect of final irrigation protocols on microhardness and erosion of root canal dentin. Microsc Res Tech 2013;76:1079-1083.

23. Kleier DJ, Averbach RE, Mehdipour 0. The sodium hypochlorite accident: experience of diplomates of the American Board of Endodontics. J Endod 2008;34:1346-1350.

Received May 23, 2014 Accepted September 19, 2014 